\title{
Chinese Private Enterprises’ Management Innovation
}

\author{
Ri $\operatorname{Nan}^{1}$ \\ ${ }^{1}$ Tianjin University of Commerce, Tianjin, China \\ Correspondence: Ri Nan, Tianjin University of Commerce, Tianjin 300134, China. Tel: 86-136-8219-7910. \\ E-mail: nanri0729@hotmail.com
}

\author{
Received: January 11, 2013 Accepted: February 5, 2013 Online Published: March 28, 2013 \\ doi:10.5539/ass.v9n4p51 \\ URL: http://dx.doi.org/10.5539/ass.v9n4p51
}

\begin{abstract}
Since the reform and opening, private enterprises of China have got a rapid development, and have done a great contribution to the continual development of national economy. However, with the change of external and internal situations, private enterprise management appears to be defective, sometimes it even does harm to the development of the enterprises. This reports aims to present of the problem of private enterprises in China. In order to solve this problem, Chinese private enterprises should accelerate the management innovation. We analyzed the necessities of enterprises' management innovation, the motivation of management innovation, obstacles to management innovation. Finally, it puts forward the countermeasures to solve the problems.
\end{abstract}

Keywords: private enterprise, China, innovation

\section{Introduction}

After more than three decades of rapid development, we see the emergence of a very strong private sector in China. Indeed, private enterprises have grown rapidly over the years and become an integral part of the Chinese economy. The Bank of Communications of China published a report regarding the wealth creation and management of China's private enterprises on May 16 2011. The report shows that while the private enterprises of China continue to make contributions to the GDP and create jobs, their wealth is also increasing rapidly. Private Chinese enterprises exported goods worth $\$ 481.3$ billion in 2010, a jump of 223 percent compared with 2005, said a report by the All-China Federation of Industry \& Commerce (ACFIC).The number of private enterprises in China exceeds 8.4 million after a yearly increase of 14.3 percent on average over the past five years. They account for more than 74 percent of China's total enterprises. However, China's private enterprises face increasing pressure from price hikes in raw materials, rising labor costs, financing difficulties, and a heavy tax burden. In order to do a good job, private enterprises have to implement management innovation. In this paper, we intend to discuss the necessities of implement management innovation, the motivation of management innovation, the obstacles to management innovation, and gave some suggestions on how to promote the management innovation.

\section{Relevant Literature Review}

There is a considerable literature regarding the Chinese private enterprises. Most of the Chinese private enterprises are family business. Family business is generally viewed as the most common form of business structure. There is also a lack of the precise definition of private business. While some researchers avoid the use of clear definitions, others apply the definitions that most suit their researches. The definitional problem is compounded when the controversy emerges about whether it should include all blood relations and in-laws. Fahed-Sreh (2009) explains a family firm as any business that is controlled or influenced by a 'single family' and which is also intended to remain in family. Brrdthistle \& Fleming (2005) and Birdthistle (2008) operate their studies on definition of family business, which regards it as 'any form of business association that is classified as an SME (less than 250 employees)and where the majority ownership is held by the family/family members in the family business and/or the family is represented on the board of Directors'. This definition seems to ignore the succession issue, which is considered as a major focus of family business. But within the context of China, the family business is undeveloped compared to those in developed countries and exist only for a very short period. Most family businesses are still within the control of first-generation. The definition of family business here just emphasizes on the majority control of ownership held by the family/family members.

In regard to the researches on family business, many people address the differences between family and non-family businesses. Harris et al. (2004) conclude that family-owed establishments are less likely to allow 
workforce engagement via a range of communication approaches in comparison to non-family firms. Others also explore issues on family business in terms of varied perspectives and emphases. Birdthistle and Fleming (2005) investigate the creation of a learning organization within the framework of family SMEs and conclude that small and medium-sized family firms display some of the characteristics of a learning organization. In relation to the development of growth strategy, Kreiser et al. (2006) suggest that family firms typically apply conservative strategies in the very beginning and often maintain tight control of the strategic decision-making process within the family unit. Rather, researches into family business have noted the strategic advantages of being embedded within family relations. Spanos et al. (2008) treat family as a real source of competitive advantage for the firm since the owner (family) is usually involved in the key decision making process.

\section{China Has Grown Because of Private Enterprises}

After more than three decades of rapid development, we see the emergence of a very strong private sector in China. Indeed, private enterprises have grown rapidly over the years and become an integral part of the Chinese economy.

Today, entrepreneurship and the development of private enterprises continue to be at the forefront of economic development. They have not only contributed significantly to economic growth, employment, and tax revenue, but also played an increasingly dominant role in management, corporate social responsibility and compliance. These contributions help China achieve development in a more sustainable way.

China's private enterprise reforms began first in agriculture in 1978 and spread from there. Agriculture accounted for most of Chinese output and most of the labor force when Mao died in 1976 and the reform period could begin. The freeing of agriculture from collective farms is the most important untold part of the Chinese growth story.

Agricultural reforms began spontaneously from below, even before the "Reform" Party Congress of 1978 that installed reformer Deng Xiaping in power. A Chinese reform official later admitted: "In fact, reform wasn't discussed. Reform wasn't listed on the agenda, nor was it mentioned in the work reports." What became known as the "contract responsibility system" was sparked spontaneously by eighteen peasants from Xiaogang village in Anhui province. They secretly divided communal land in November 1978 and agreed to farm their plots individually, each contributing their share of the state quota. The state got its due and the peasants kept what was left over. The peasants' separation of their land from the collective farm was illegal, highly dangerous, and done without the approval of regional officials.

As agricultural production soared, Deng Xiaping and his CPC realized that they should not resist something that was working. By 1982, more than 90 percent of rural dwellers worked under the contract responsibility system, but they were allowed only one- to three-year contracts on their land. It was only in 2003 that the state gave out longer-term leases.

The spontaneous reforms in agriculture meant that new supplies of food products needed markets and that markets needed infrastructure. Rural dwellers created a private trade network, and, within one year, most state food stores were out of business. Rural entrepreneurs then created new businesses, such as hotels, services, private restaurants, and small-scale manufacturing, through the three Fs (friends, family and fools). They bribed local officials to register their companies as "township and village enterprises." They created fake "red hat" enterprises, that is, private companies masquerading as state companies, and sham collective enterprises, or they used state enterprises to issue receipts and open bank accounts. Large private manufacturing firms developed first in predominantly agricultural provinces. China's largest agribusiness was founded by brothers who left the city to found their company in rural Sichuan. Rural entrepreneurs built the largest refrigeration and air-conditioning companies in China.

\section{The Necessities of Chinese Enterprises' Management Innovation}

Most of the Chinese private enterprises are family business, highly centralized managed. This model can save costs, and maintain the flexibility of operation. However, this kind of management model also has a lot of problems, and it caused more problems with the change of environments and out of the enterprises, sometimes these shortcomings even constrain the development of private enterprises. Private enterprises have to improve their management model if they want to be strong in the future.

\subsection{Expand the Operate and Assets Scale}

The process and function of the enterprise will become more and more complicated as the Chinese enterprises' assets increased. If we still use the old information management, internal and external information of the enterprises will both become confusing. This will hinder the rapid development of the enterprises. Many Chinese 
private businesses have such problems. Some private enterprises' employees behave against the enterprises' regulations and will be discovered only when such behavior is causing serious consequences. Therefore, private enterprises should take new management methods before expanding. The primary task is to create a new organization structure, in which the corporations' internal information will be transmitted in time, and the leader of the enterprises can get more suggestions for the enterprises' operation.

\subsection{Enter into Capital-Intensive and Technology Intensive Industries}

As China's reform and opening up process, some of the best private enterprises enter into capital-intensive industries and technology intensive industries in which strategic management is very important to enterprises' survival and development. Sorry to private enterprises, most of them haven't even thought of strategic management. They don't have a clear idea of their market orientation, competitors or competitive environment. Affected by experiences which they got at the process of starting business, executives still take the development of enterprises as a kind of speculation. To those private enterprises which have entered into technology intensive industries, competitive edge have to be won by create self-owned core technologies. Those private enterprises are kind of technology based businesses or higher level knowledge-based enterprises, in which the research of knowledge management and technical research and development has become the key to enterprises' development. Therefore, both the organization and its operating system have to change to get along well with the need of knowledge management. This is a great reform to management idea, management technology and management method.

\subsection{Make Best Use of Human Resources}

At the beginning of starting a business, the entrepreneurs' social capital and ability to find opportunities are very important. Owing to these good entrepreneurs, private enterprises grew up fast in the past years when there were not enough products in the market. However, the market is now full of products and with fierce competition. Private enterprises will end in disaster if they still depend on the entrepreneurs' social capital and ability to develop. Private enterprises' owners should change the idea that developing is the job of themselves, welcome workers with great abilities to join the enterprises, and let the human resources become the engine of enterprises' development. In order to do this, private enterprises have to change their human resource management, which are not attractive to workers. They should pay more attention to the need of workers, to attract good workers to join in, to train old workers to make them more talent, and to give more inspiration to the employees to keep them.

\subsection{Develop}

The process of private enterprises' develop is a strategic process, which needs a long-term development strategy. The strategy should change as the situations of the enterprises change. That is to say, the strategy should change with the market competition, enterprises' competitive edge, etc.

\section{Innovative Power of Private Enterprises' Management}

Innovative power is the main reason to conduct and sustained the innovation in enterprise's development. The power of innovation is complicated. Private enterprise's management innovative power comes mainly from the following aspects:

\subsection{Interests}

People play a very important part in enterprises. It is one of the key factors to enterprises' survival and development. Different people have different positions, thus their power, responsibility and interests are also different. The main task of management innovation is to abolish the existing power, responsibility, interests and establish a new pattern according to the environmental requirements. Everyone in the enterprise wants to gain more interests according to the innovation. Investors care about the enterprise's development and capital value, seeking for maximize investment returns. On one hand, they want to further enhance enterprise's vitality and sustain the growth with the help of management innovation; on the other hand, they hope that by implementing management innovation, they can strengthen the supervision and control of the enterprise so as to protect their rights. Proprietors want maximize their utility through innovation. That is to say, they want secure more power, more income, subsidies, and to promote their positions. A common worker may want to secure more income, better treatment, and effectively protect the legitimate rights and interests. Other stakeholders, such as the government, banks, the community, the creditors, partners, all want to protect their own interests and gain a higher income through management system innovation. The desire to gain more interests can become the engine of management innovation. 


\subsection{Psychological Power}

Innovation is promoted not only by interests, but also by psychology. It is one of the most important human needs. The fulfillment of innovation on success, personal values and responsibilities often become the power of innovation. Both the investors and proprietors want to show their abilities and values from successful management innovation. For professional managers, they have to responsible for the enterprise according to professional and ethical requirements. Therefore, they have a strong will to lead the enterprise to success through innovation. Besides, there is still someone who wants to take greater social responsibilities for society to make more contributions and become a noble man through management innovation. All these wishes and believes are psychological power which will promote management innovation.

\subsection{Enterprises Themselves}

As an organism, enterprises have demand to innovating in certain condition. As the environment inside and outside the enterprises change, the existing management model doesn't conform to the new situation, thus the development of the enterprises will stop. In such case, managers will have to change the exiting management model. This kind of innovation is forced by the enterprises themselves. If the managers fail to notice the problem and take no action, the enterprise will have great trouble, some even will bankrupt. Besides, changes of the society, policy and law can also force the enterprises to improve their management.

\section{Obstacles to Private Enterprises' Management Innovation}

\subsection{The Low Quality of Manager}

Owing to historical reasons, most of the private enterprises' owners haven't received the formal education, not to mention comprehensive and systematic business administration training. Thus they don't have enough management theories, methods and skills. Some of them even don't know English and computers. These problems may hamper their work. What's more, some of the owners are easy to be content and not aggressive. These may not be good for the enterprises' development.

\subsection{Inefficient Management Model}

At present most of the private enterprises use the family management model. The distinct characteristic of this management model is that owners or their relatives run the enterprises and control the whole production and operation process all by themselves. It is proved that this kind of management model is good for starting a business but bad for developing a business. At the beginning of starting a business, this kind of model can collect talents and capital at a very low cost. For most of the talents belong to a single family, their interests are the same. So these talents will devote all they have to fight for the enterprise together. This hard work sometimes really works. It can help the enterprise grow up into a bigger scale enterprise with competitive advantage. However, as the enterprises' scales grow, the old family management model becomes more and more inefficient. First, owners treat their relatives and exotic workers differently make the exotic workers unhappy. Second, the owners just follow their feelings to make decisions for the enterprises without listen to others. Third, the managerial authority will be passed on to their descents. All these factors make the enterprises hard to develop.

\subsection{Management Belief}

Private enterprises choose family management model indicate that they take the family interests as the most important thing. This can be explained by Chinese traditional culture. First, in Chinese traditional culture, family is the basic economic unit. The chief function of family is the ownership of enterprises' wealth. Second, "obey" is very important in a family which means that people have to follow their parents' decisions. These factors give the owners absolute decision-making rights. All the descents have to follow these decisions to defend the family's interests. Followed by these believes, many private enterprises seeking for the maximum family interests at the cost of social interests. For example, some private enterprises defraud tax, produce counterfeited products. All these bad behavior not only caused bad effects on the social economic order and marketing order but also damaged the social image of the private enterprises. And these effects damaged the living environment of the private enterprises in return.

\subsection{Human Resources Management}

\subsubsection{The Unfair Hiring System}

Most of Chinese private enterprises choose family management model, that is to say, they hire workers according to relationships. If the workers are close to the owner, like the owner's relatives, students, friends and so on, they will be considered important and trustworthy. On the contrary, if the relationship between workers and the owners is just employees and employers, the workers will be ignored and distrusted. What's more, the 
owners give different treatments to the workers according to relationships, too. Those who are close to the owners will get better pay. This kind of human resource management makes the common workers very unhappy, they find the system unfair, have no security and have no sense of belonging. Therefore, many workers quit their jobs in the private enterprises. When talents are gone, the private enterprises will end in disaster.

\subsubsection{Ignore Talent: It Is True That the Owners Are Very Clever}

When starting a business, all decisions are made by the owners themselves. And these decisions really works, the enterprises grow from infants to sizable enterprises. In some ways, there will be no private enterprises if there were no such excellent owners. However, these legends also have some bad effects. Some of the owners will become conceit and opinionated. They don't pay much attention to the talents. They believe that their own intelligence can handle all the troubles. Many owners hire talents just for decorating the enterprise. This is very dangerous for an enterprise to live in nowadays.

\subsubsection{Little Training for the Employees: In Order to Promote}

The enterprise's development, some private enterprises try many ways to attract excellent graduates to join in. However, most of the enterprises site in middle and small city. Even some of the graduates want to work there, they don't want to take their registered permanent residence there. In this case, the enterprises will have no security on keeping these graduates. They fear that these graduates will leave after a few years. So they have no incentive to train these graduates. On the other hand, no training for the graduates makes the graduates very worry about the future. How to solve this vicious circle is very important for private enterprises' development.

\subsubsection{The Lack of Effective Incentive Mechanisms}

Effective incentive mechanisms can arouse the employees' potential abilities, create a homegrown innovation environment, attract talents in and out of the enterprise. However, most of the Chinese private enterprises ignore the talents management, ignore employees' needs, and lack effective incentive mechanisms. In the long term, these problems will become the bottle-neck which obstructs stable development of an enterprise.

\section{The Ways to Enforce Administrative Creation}

With the implementation of China's economic system reform, the external environment of the management innovation will be better and better. Enterprises should also take actions to promote innovation.

\subsection{Pay Attention to Management Innovation}

Management is not only a kind of science but also productive forces. Good management is an important factor to enterprises' long-term development. The workers, especially the managers should pay attention to enterprises' management, and make it an engine to management innovation.

\subsection{Improve the Quality of the Entrepreneur}

Entrepreneurs are the soul of enterprises. Their qualities determine the management qualities and enterprises' development in the future. Therefore, the improvement of their qualities is the key factor to enterprises' development. Generally speaking, a successful entrepreneur should have the following qualities: first, he must have a wide range of knowledge and skilled management techniques. Second, he must be good at communicating with others. Third, he must be very aggressive. Forth, he must have a strong sense of responsibilities. Only when an entrepreneur has these characteristics can he promise the enterprise a bright future while do no harm to the society.

\subsection{Improve the Property Rights System}

The property rights structure of most private enterprises is single and closed. It is limited to personal property rights. The problem of this kind of property rights system is that enterprises may have difficulties in getting rid of personal and family control system, departing the ownership and management power, changing the investor's model into managerial management model, and accepting social capital. These problems will set back the enterprises' development. Therefore, if the private enterprises want to grow bigger and stronger, they have to get rid of the family management model and welcome other investors to join in. In this way, the shortcomings of closed property rights will be solved, more capital can be used for the enterprises' expansion.

\subsection{Change the Management Model}

Nowadays the property rights are belonging to a single family. The leader of the family makes decisions for the enterprise. When the leader quit, the management power will be passed on to his descents. However, not all descents are as clever as their ancestors. Sometimes, they are not good at operating an enterprise and this will bring disaster to the enterprise. To avoid this tragedy, the owner should choose the most suitable successor to be 
the manager, either he is the descent or not, and let the unsuitable descents be shareholders. "Most suitable" means he is best at manage an enterprise.

\subsection{Form an Environment of Management Innovation Culture}

For enterprises, the most important value of management innovation is that the enterprises' problems can be solved much better. The characteristics and practices of management innovation show that management innovation often appears when workers have different ideas in solving a same problem. That is to say, the workers get stuck, hold different opinions in solving them, discuss advantages and disadvantages of these solutions, and finally create a best solution. This best solution may be considered as part of the enterprises' management innovations. So enterprises can pay more attention to cultivate management innovation environment. Call for the workers to join in the management innovation so as to create more solutions.

\subsection{Try to Make the Enterprises and Social Live in Harmony}

Enterprises are profit-making organizations, and seeking for the maximum interests is one of their duties. However, enterprises' interests can't be counted only by profits at present. They must consider interests both at present and in the future. If they only seek for profits at present, and smuggling, cheating, producing fake products and so on, their social image will be very bad. In the long run, people wouldn't buy their products. And this will finally ruin the enterprises' future. So enterprises should put the future interests and present interests together, form a good social image so as to live in harmony with the society.

\subsection{Improve the Human Resource Management System}

In order to break the bottlenecks of lacking talents, private enterprises have to pay more attention to their employees, select employees by their abilities instead of by relationships. Besides, enterprises should accept all kinds of talents, especially those who are good at research, development and management. Furthermore, private enterprises should give different employees different incentives. That means enterprises should give employees prizes which they need most. For example, if an employee wants to promote himself, enterprises should give him more opportunities to study and give him a promotion when he deserves it. Finally, private enterprises should create a good, comfortable environment so that employees can do their best.

\section{Conclusion}

The main purpose of this paper is to give some suggestions on how to innovate private enterprises' management. We analyze the necessities of private enterprises' management innovation, the motivation of management innovation, the obstacles to management innovation, and finally we come to the solution. We think that, in order to develop, the private enterprise should pay attention to management innovation, improve the quality of the entrepreneur, improve the property rights system, change the management model, form an environment of management innovation culture, try to make the enterprises and social live in harmony, and improve the human resource management system.

\section{References}

Birdthistle, N. (2008). Family SMEs in Ireland as learning organizations. The Learning Organization, 15(5). http://dx.doi.org/10.1108/09696470810898393

Birdthistle, N., \& Fleming, P. (2005). Creating a learning organization within the family business: an Irish perspective. Journal of European Industrial Training, 29(9). http://dx.doi.org/10.1108/03090590510629858

Chua, J. H., James, J. C., \& Lloyd, P. (2006, Summer). Steier. Extending the theoretical horizons of family business research. Entrepreneurship Theory and Practice.

Fahed-Sreih, J. (2009). An exploratory study on a new corporate governance mechanism: Evidence from small family firms. Management Research News, 32(1). http://dx.doi.org/10.1108/01409170910922023

$\mathrm{Gu}, \mathrm{B}$. R. (2006). Culture obstacles to private enterprises' management innovation. Enterprise Development Forum, (12).

Harris, M., \& Raviv, A. (1991). The Theory of Capital Structure. Journal of Finance, 46(1). http://dx.doi.org/10.1111/j.1540-6261.1991.tb03753.x

Hong, S. (2003). Modern Institutional Economics. Beijing: Peking University Press.

Klyver, K. (2007). Shifting family involvement during the entrepreneurial process. International Journal of Entrepreneurial Behaviour \&Research, 13(5). http://dx.doi.org/10.1108/13552550710780867

Kreiser, P. M., Ojala, J., Lamberg, J. A., \& Melander, A. (2006). A historical investigation of the strategic process 
within family firms. Journal of Management History, 12(1). http://dx.doi.org/10.1108/13552520610638300

Liu, K. W. (2005). Analysis on private enterprises' management innovation. Journal of Enshi Technical College, (1).

Liu, X. H. (n.d.). How to improve incentive system in private enterprises' management. China Business \& Trade. Spanos, L. J., Tsipouri, L. J., \& Xanthakis, M. D. (2008). Corporate governance rating of family firms at the Athens exchange market. Managerial Finance, 34(7). http://dx.doi.org/10.1108/03074350810874424

Wei, L., Ning, X., \& Ning, J. (2010). Opinions on improve private enterprises' management. Mechanical Management and Development, (2). 